\title{
Faktor-faktor yang mempengaruhi tingkat pengangguran dan kemiskinan di kota samarinda
}

\author{
Dahma Amar Ramdhan ${ }^{1}$, Djoko Setyadi², Adi Wijaya ${ }^{3}$ \\ Magister Ilmu Ekonomi, Fakultas Ekonomi dan Bisnis Universitas Mulawarman, Samarinda. \\ ${ }^{1}$ Email: dahma.amar.ramdhan@mhs.feb.unmul.ac.id \\ ${ }^{2}$ Email: djoko.setyadi@feb.unmul.ac.id \\ ${ }^{3}$ Email: adi.wijaya@feb.unmul.ac.id
}

\begin{abstract}
Abstrak
Penelitian ini bertujuan untuk menganalisis dan mengetahui pengaruh pertumbuhan ekonomi, upah minimum kota (UMK), tingkat pendidikan, dan inflasi terhadap tingkat pengangguran dan kemiskinan di Kota Samarinda. Data yang digunakan dalam penelitian ini adalah data sekunder pada tahun 2005-2014. Alat analisis yang digunakan adalah analisis jalur (path analysis). Perangkat lunak yang digunakan untuk melakukan analisis adalah IBM-SPSS Versi 23. Hasil penelitian menunjukkan bahwa dalam mempengaruhi tingkat pengangguran, pertumbuhan ekonomiberpengaruh langsung dan tidak signifikan dengan nilai pengaruh 0,269 dan signifikansi $0,177>0,10$, upah minimum kotaberpengaruh langsung dan signifikan dengan nilai pengaruh $-1,269$ dan signifikansi $0,032<0,10$, tingkat pendidikan berpengaruh langsung dan tidak signifikan dengan nilai pengaruh 0,554 dan signifikansi $0,255>0,10$, sertainflasi berpengaruh langsung dan tidak signifikan dengan nilai pengaruh 0,184 dan signifikansi $0,352>0,10$.
\end{abstract}

Kata Kunci: Pertumbuhan ekonomi; upah minimum kota

\section{Factors affecting unemployment and poverty in the city of samarinda}

\begin{abstract}
This study aims to analyze and determine the effect of economic growth, urban minimum wage $(U M K)$, education level, and inflation on unemployment and poverty in the city of Samarinda. Data used in this research is secondary data in year 2005-2014. The analysis tool used is path analysis (path analysis). The software used to perform the analysis was IBM-SPSS Version 23. The results showed that in affecting the unemployment rate, economic growth had a direct and insignificant effect with the influence value of 0.269 and the significance of 0.177> 0.10, the minimum wage of the kotaber had a direct and significant influence with the value of influence -1,269 and significance $0,032<0,10$, education level have direct and insignificant effect with influence value 0,554 and significance 0,255>0,10, sertainflasi have direct effect and not significant with value influence 0,184 and significance 0,352>0,10.
\end{abstract}

Keywords: Economic growth; city minimum wage 


\section{PENDAHULUAN}

Kemiskinan merupakan masalah sosial yang senantiasa hadir di tengah-tengah masyarakat. Kemiskinan juga merupakan masalah sosial yang senantiasa relevan untuk dikaji secara terusmenerus, bukan saja karena masalah kemiskinan telah ada sejak lama, melainkan karena hingga kini kemiskinan belum bisa dientaskan dan bahkan gejalanya semakin meningkat sejalan dengan krisis multidimensional yang terjadi. Kemiskinan ditandai oleh keterbelakangan dan pengangguran yang selanjutnya meningkat menjadi pemicu ketimpangan pendapatan dan kesenjangan antar golongan penduduk. Kesenjangan dan pelebaran jurang antara si kaya dan si miskin tidak mungkin untuk terus dibiarkan karena akan menimbulkan berbagai persoalan, baik persoalan sosial maupun persoalan politik di masa yang akan datang.

Dalam rangka mengurangi tingkat kemiskinan di suatu daerah, penanggulangan kemiskinan harus dilakukan secara menyeluruh, yang berarti menyangkut seluruh penyebab kemiskinan. Beberapa diantaranya yang menjadi bagian dari penanggulangan kemiskinan yang perlu tetap ditindaklanjuti dan disempurnakan implementasinya adalah pemerataan pertumbuhan ekonomi, peningkatan dan pemerataan tingkat upah, peningkatan pendidikan masyarakat, pengendalian inflasi, serta perluasan lapangan kerja.

Masalah kemiskinan di Kota Samarinda cukup kompleks karena beragamnya kondisi sosial budaya masyarakat dan pengalaman kemiskinan yang berbeda. Jumlah penduduk miskin di Kota Samarinda mengalami fluktuasi sejak tahun 2005 hingga 2014. Fluktuasi jumlah penduduk miskin tersebut bahkan cenderung meningkat selama kurun waktu tersebut. Hal ini menunjukkan bahwa kebijakan penanggulangan kemiskinan yang telah diterapkan oleh Pemerintah Daerah Kota Samarinda selama kurun waktu tersebut belum maksimal dalam mengurangi jumlah penduduk miskin di Kota Samarinda.

Permasalahan kemiskinan di Kota Samarinda tidak terlepas dari banyaknya jumlah pengangguran selama kurun waktu yang sama. Hanya saja, jumlah pengangguran yang juga berfluktuasi pada tahun 2005-2014 relatif mengalami penurunan. Hal ini cukup aneh karena seharusnya tingkat kemiskinan berkorelasi positif (searah) dengan tingkat pengangguran. Artinya, jika tingkat pengangguran relatif menurun, maka seharusnya tingkat kemiskinan juga relatif menurun. Namun, kenyataan yang terjadi di lapangan menunjukkan hal yang berbeda.

Berkaitan dengan upaya penanggulangan kemiskinan dan pengangguran, pertumbuhan ekonomi merupakan salah satu faktor yang turut mempengaruhi berkurangnya angka kemiskinan dan pengangguran di Kota Samarinda. Selain pertumbuhan ekonomi, tingkat pendidikan juga memiliki peranan yang sangat penting dalam rangka mengurangi angka kemiskinan dan pengangguran di Kota Samarinda. Tingkat pendidikan yang dimaksud adalah rata-rata lama sekolah yang telah ditempuh oleh seluruh penduduk di Kota Samarinda. Rata-rata lama sekolah di Kota Samarinda selalu mengalami peningkatan sejak tahun 2005 hingga 2014. Hal ini menunjukkan bahwa angka putus sekolah di kota tersebut semakin berkurang, dimana semakin banyak masyarakat yang sadar akan pentingnya pendidikan. Namun, semakin membaiknya tingkat pendidikan ini hanya berkorelasi negatif (berlawanan arah) dengan angka pengangguran, sedangkan korelasinya dengan angka kemiskinan menunjukkan hubungan yang searah, dimana angka kemiskinan di Kota Samarinda cenderung meningkat selama kurun waktu yang sama.

Serupa dengan tingkat pendidikan, inflasi juga memiliki peranan yang sangat penting dalam rangka mengurangi angka kemiskinan dan pengangguran di Kota Samarinda. Selama kurun waktu tahun 2005-2014, inflasi di Kota Samarinda berfluktuasi dan cenderung mengalami penurunan. Hal ini sangat baik bagi perekonomian Kota Samarinda karena semakin kecil angka inflasi maka semakin berkurang juga angka kemiskinan dan pengangguran. Namun, kenyataan yang terjadi di lapangan hanya jumlah pengangguran yang berkurang seiring dengan semakin kecilnya angka inflasi di Kota Samarinda, sedangkan jumlah penduduk miskin justru meningkat selama kurun waktu yang sama, dimana seharusnya jumlah penduduk miskin tersebut juga berkurang seperti halnya yang terjadi pada jumlah pengangguran.

Di sisi lain, besaran Upah Minimum Kota (UMK) yang ditetapkan di Kota Samarinda juga memiliki peranan dalam rangka mengurangi angka kemiskinan dan pengangguran di kota tersebut. 
Namun, menurut para ahli ekonomi, peningkatan yang terjadi pada upah minimum hanya berkorelasi negatif dengan tingkat kemiskinan, dimana semakin tinggi upah minimum maka akan mengurangi angka kemiskinan. Sedangkan, berkaitan dengan pengangguran, peningkatan upah minimum berkorelasi positif dengan tingkat pengangguran, dimana semakin tinggi upah minimum maka semakin sedikit permintaan terhadap tenaga kerja yang berarti semakin banyak pengangguran.

Pemerintah Daerah Kota Samarinda telah menetapkan besarnya UMK, dimana UMK tersebut selalu meningkat sejak tahun 2005 hingga 2014. UMK yang selalu meningkat tersebut seharusnya dapat mengurangi jumlah penduduk miskin di Kota Samarinda. Namun, kenyataan yang terjadi di lapangan adalah jumlah penduduk miskin cenderung meningkat walaupun UMK yang ditetapkan selalu meningkat selama kurun waktu tahun 2005-2014. Selain itu, UMK yang selalu meningkat tersebut justru mengakibatkan jumlah pengangguran cenderung mengalami penurunan selama kurun waktu yang sama.

\section{Kajian Pustaka}

\section{Kemiskinan}

Kemiskinan adalah kondisi sosial ekonomi seseorang atau sekelompok orang yang tidak terpenuhi hak-hak dasarnya untuk mempertahankan dan mengembangkan kehidupan yang bermartabat. Kebutuhan dasar yang menjadi hak seseorang atau sekelompok orang meliputi kebutuhan pangan, kesehatan, pendidikan, pekerjaan, perumahan, air bersih, pertanahan, sumberdaya alam, lingkungan hidup, rasa aman dari perlakuan atau ancaman tindak kekerasan, dan hak untuk berpartisipasi dalam penyelenggaraan kehidupan sosial dan politik. Kondisi yang disebut miskin ini juga berlaku pada mereka yang bekerja akan tetapi pendapatannya tidak mencukupi untuk memenuhi kebutuhan dasarnya. Kemiskinan umumnya dilukiskan sebagai rendahnya pendapatan untuk memenuhi kebutuhan pokok. Di Indonesia, pengukuran kemiskinan menggunakan pendekatan kebutuhan dasar (basic needs). Berdasarkan pendekatan kebutuhan dasar, ada tiga indikator kemiskinan yang digunakan, yaitu indeks per kepala (head count index), indeks kedalaman kemiskinan (poverty gap index), dan indeks keparahan kemiskinan (poverty severity index). Headcount indexdigunakan untuk mengukur kebutuhan absolut yang terdiri dari dua komponen, yaitu garis kemiskinan makanan dan garis kemiskinan non makanan. Garis kemiskinan sebagai dasar untuk perhitungan head count indexditentukan berdasarkanbatas pengeluaran minimum untuk konsumsi makanan setara dengan $2100 \mathrm{kkal}$ per hari dan konsumsi non makanan (Yarlina Yacoub, 2012: 177).

\section{Pengangguran}

Pengangguran atau tuna karya adalah istilah untuk orang yang tidak bekerja sama sekali, sedang mencari kerja, bekerja kurang dari dua hari selama seminggu, atau seseorang yang sedang berusaha mendapatkan pekerjaan yang layak. Pengangguran umumnya disebabkan oleh jumlah angkatan kerja atau para pencari kerja yang tidak sebanding dengan jumlah lapangan kerja yang ada (Albertus Aditya, 2016). Serupa dengan pengertian di atas, Sadono Sukirno (2004: 28) mengatakan bahwa pengangguran adalah seseorang yang sudah digolongkan dalam angkatan kerja, yang secara aktif sedang mencari pekerjaan pada suatu tingkat upah tertentu, tetapi tidak dapat memperoleh pekerjaan yang diinginkan. Tingkat pengangguran menunjukkan persentase dari individu-individu yang ingin bekerja namun tidak memiliki perkerjaan. Seseorang dianggap menjadi penganggur jika tidak bekerja namun masih menunggu untuk mendapatkan pekerjaan.

\section{Pertumbuhan Ekonomi}

Pertumbuhan ekonomi merupakan pertambahan relatif nilai barang dan jasa dalam satu periode (satu tahun). Pertambahan nilai barang dan jasa ini dapat dilihat dari Produk Domestik Regional Bruto (PDRB). Nilai barang dan jasa dalam PDRB meningkat karena jumlah dan harga dari barang dan jasa itu sendiri. Untuk menghilangkan pengaruh kenaikan harga, maka pertumbuhan ekonomi dihitung dengan nilai PDRB atas dasar harga konstan. 


\section{Upah Minimum}

Upah adalah suatu penerimaan berupa imbalan dari pemberi kerja yang diberikan kepada penerima kerja atas pekerjaan atau jasa yang telah atau akan dilakukan. Semakin tinggi tingkat upah, semakin kecil permintaan pengusaha akan tenaga kerja. Kenaikan tingkat upah akan diikuti oleh turunnya jumlah tenaga kerja yang diminta, yang berarti akan menyebabkan bertambahnya jumlah pengangguran (Haryani, 2002: 99). Upah minimum adalah suatu standar minimum yang digunakan oleh para pengusaha atau pelaku industri untuk memberikan upah kepada pekerja di lingkungan usaha atau kerjanya. Menurut Peraturan Pemerintah No. 78 Tahun 2015 tentang Pengupahan, Pasal 41 ayat 2, "upah minimum merupakan upah bulanan terendah yang terdiri atas: a. upah tanpa tunjangan; atau b. upah pokok termasuk tunjangan tetap". Peraturan Pemerintah ini juga menegaskan bahwa upah minimum hanya berlaku bagi pekerja/buruh dengan masa kerja kurang dari 1 (satu) tahun pada perusahaan yang bersangkutan. Sementara itu, upah bagi pekerja/buruh dengan masa kerja 1 (satu) tahun atau lebih dirundingkan secara bipartit antara pekerja dengan pengusaha di perusahaan yang bersangkutan.

\section{Tingkat Pendidikan}

John Dewey dalam Sutarman Tarjo (2011) mengartikan pendidikan adalah suatu proses pembentukan kecakapan fundamental, baik secara intelektual maupun emosional, kearah alam dan sesama manusia. Jean Jaques Rousseau menjelaskan bahwa pendidikan adalah pembekalan yang tidak ada pada saat anak-anak, akan tetapi dibutuhkan pada saat dewasa (Sutarman Tarjo, 2011). Serupa dengan pendapat di atas, G. Terry Page, J.B. Thomas, dan A.R. Marshall mendefinisikan pendidikan sebagai proses pengembangan kemampuan dan perilaku manusia secara keseluruhan (Endah, et al., 2010). Dalam upaya mencapai pembangunan ekonomi yang berkelanjutan, sektor pendidikan memainkan peranan sangat strategis dalam mendukung proses produksi dan aktivitas ekonomi lainnya. Dalam konteks ini, pendidikan dianggap sebagai alat untuk mencapai target yang berkelanjutan, karena dengan pendidikan, aktivitas pembangunan dapat tercapai sehingga peluang untuk meningkatkan kualitas hidup di masa mendatang akan lebih baik.

\section{Inflasi}

Boediono (1999) menyatakan bahwa definisi singkat dari inflasi adalah kecenderungan dari harga-harga untuk naik secara umum dan terus-menerus. Kenaikan harga dari satu atau dua barang saja tidak disebut inflasi, kecuali bila kenaikan tersebut meluas kepada (atau mengakibatkan kenaikan) sebagian besar dari harga barang-barang lain. Kenaikan harga-harga karena musiman, menjelang harihari besar, atau yang terjadi sekali saja (dan tidak mempunyai pengaruh lanjutan) tidak disebut inflasi. Serupa dengan pendapat di atas, Sukirno (2002) menyatakan bahwa inflasi dapat didefinisikan sebagai suatu proses kenaikan harga-harga yang berlaku dalamsuatu perekonomian.

\section{Hubungan Antar Variabel}

\section{1) Hubungan Pertumbuhan Ekonomi dengan Pengangguran}

Arthur Okun mengemukakan sebuah teori yang mempelajari hubungan antara tingkat pengangguran dengan GDP (dalam hal ini berkaitan dengan pertumbuhan ekonomi) yang dikenal sebagai Hukum Okun. Konsep dari Hukum Okun didasari oleh hasil observasi terhadap data GDP Amerika Serikat. Hukum Okun menjelaskan bahwa tingkat pengangguran memiliki hubungan negatif dengan pertumbuhan GDP. Hal ini menjelaskan, jika GDP mengalami kenaikan, maka tingkat pengangguran akan turun. Jika GDP tidak mengalami pertumbuhan, maka tingkat pengangguran akan tetap pada tingkat yang sama, bahkan akan naik sebesar $1,5 \%$ dari kondisi sebelumnya (Mankiw, 2006: 248, terjemahan Haris Munandar, 2006).

\section{2) Hubungan Upah Minimum dengan Pengangguran}

Semakin tinggi tingkat upah, semakin kecil permintaan pengusaha akan tenaga kerja. Kenaikan tingkat upah akan diikuti oleh turunnya jumlah tenaga kerja yang diminta, yang berarti akan menyebabkan bertambahnya jumlah pengangguran (Haryani, 2002: 99). Menurut Todaro (2000, 
terjemahan Haris Munandar, 2000), semakin tinggi tingkat upah yang ditawarkan kepada tenaga kerja maka akan menurunkan tingkat penyerapan tenaga kerja. Hal ini berarti bahwa pengangguran akan meningkat. Pendapat yang sama dikemukakan oleh Sumarsono (2003), yaitu besar kecilnya upah akan mempengaruhi tinggi rendahnya biaya produksi perusahaan. Biaya produksi yang tinggi meningkatkan harga produk yang pada akhirnya membuat permintaan terhadap produk berkurang. Kondisi ini memaksa produsen untuk mengurangi jumlah produk yang dihasilkan, yang selanjutnya juga dapat mengurangi permintaan tenaga kerja, termasuk pemutusan hubungan kerja yang mengakibatkan meningkatnya jumlah pengangguran. Serupa dengan pendapat di atas, Ehrenberg dan Smith (1998: 68) dalam Abdul Haris (2013: 20) menyatakan apabila terdapat kenaikan tingkat upah rata-rata, maka akan diikuti oleh turunnya jumlah tenaga kerja yang diminta, berarti akan terjadi pengangguran. Jika dibalik, turunnya tingkat upah rata-rata akan diikuti oleh meningkatnya kesempatan kerja, sehingga dapat dikatakan bahwa kesempatan kerja mempunyai hubungan terbalik dengan tingkat upah, artinya pengangguran mempunyai hubungan searah dengan tingkat upah.

\section{3) Hubungan Tingkat Pendidikan dengan Pengangguran}

Berkaitan dengan upaya pencapaian pembangunan ekonomi yang berkelanjutan, sektor pendidikan memainkan peranan sangat strategis dalam mendukung proses produksi dan aktivitas ekonomi lainnya. Dalam konteks ini, pendidikan dianggap sebagai alat untuk mencapai target yang berkelanjutan, karena dengan pendidikan yang lebih tinggi, jumlah tenaga kerja yang terserap akan meningkat sehingga jumlah pengangguran berkurang. Dengan demikian, aktivitas pembangunan dapat tercapai sehingga peluang untuk meningkatkan kualitas hidup di masa mendatang akan lebih baik. Analisis atas investasi dalam bidang pendidikan menyatu dalam pendekatan modal manusia. Modal manusia (human capital) adalah istilah yang sering digunakan oleh para ekonom untuk pendidikan, kesehatan, dan kapasitas manusia lainnya yang dapat meningkatkan produktivitas jika hal-hal tersebut ditingkatkan. Pendidikan memainkan kunci dalam membentuk kemampuan untuk menyerap teknologi modern dan untuk mengembangkan kapasitas seseorang agar tercipta pertumbuhan serta pembangunan yang berkelanjutan (Todaro dan Smith, 2004, terjemahan Haris Munandar, 2004).

\section{4) Hubungan Inflasi dengan Pengangguran}

Tingkat inflasi memiliki hubungan positif terhadap pengangguran. Jika tingkat inflasi yang dihitung adalah inflasi yang terjadi pada harga-harga secara umum, maka tingginya tingkat inflasi yang terjadi akan berakibat pada peningkatan pada tingkat bunga (pinjaman). Oleh karena itu, dengan tingkat bunga yang tinggi akan mengurangi investasi untuk mengembangkan sektor-sektor yang produktif. Hal ini akan berpengaruh pada jumlah pengangguran yang tinggi karena rendahnya kesempatan kerja sebagai akibat dari rendahnya investasi (Sukirno, 2002).

\section{5) Hubungan Pertumbuhan Ekonomi dengan Kemiskinan}

Hubungan antara pertumbuhan ekonomi dan kemiskinan adalah pertumbuhan ekonomi yang tinggi dan berkelanjutan menyebabkan peningkatan permintaan akan tenaga kerja dan peningkatan upah yang pada akhirnya mengurangi kemiskinan. Pendapatan yang lebih baik meningkatkan produktivitas tenaga kerja dan pertumbuhan ekonomi. Pertumbuhan ekonomi juga memperbaiki pendapatan publik dan meningkatkan pengeluaran pemerintah untuk prasarana fisik dan sosial, sehingga membantu mengurangi kemiskinan (Sukirno, 2006). Pertumbuhan ekonomi dapat dijadikan indikator untuk melihat sejauh mana distribusi pendapatan telah menyebar ke berbagai lapisan masyarakat serta siapa saja yang telah menikmati hasilnya. Sehingga, menurunnya pertumbuhan ekonomi berdampak pada kualitas konsumsi rumah tangga. Kuznets (2001) dalam Todaro (2002) menyatakanbahwa pertumbuhan ekonomi dan kemiskinan mempunyai korelasi yang sangat kuat, karena pada tahap awal proses pembangunan, tingkat kemiskinan cenderung meningkat dan pada saat mendekati tahap akhir pembangunan jumlah orang miskin berangsur-angsur berkurang.

\section{6) Hubungan Upah Minimum dengan Kemiskinan}

Menurut para ahli ekonomi, peningkatan upah minimum dipercaya meningkatkan standar kehidupan buruh, mengurangi kemiskinan, mendorong perusahaan lebih efisien, sekaligus 
menciptakan efek beruntun lewat peningkatan konsumsi ke peluang kerja baru. Peningkatan upah minimum juga akan mengurangi beban pemerintah untuk biaya jaminan sosial akibat turunnya kelompok miskin yang disubsidi. Upah yang semakin tinggi mendorong banyak orang memasuki pasar kerja formal dibandingkan bekerja di sektor informal dan ilegal, dan terutama mempercepat penghapusan kebijakan buruh murah menuju kebijakan buruh upah layak (Budi Santoso, 2012).

\section{7) Hubungan Tingkat Pendidikan dengan Kemiskinan}

Secara umum, kemiskinan akan menghalangi seseorang untuk memperoleh pendidikan yang lebih tinggi. Jika investasi pendidikan dilakukan, maka akan mampu meningkatkan kualitas sumberdaya manusia yang diperlihatkan dengan meningkatnya pengetahuan dan keterampilan seseorang. Menurut Simmons, dalam Todaro (1994, terjemahan Haris Munandar, 1994), pendidikan di banyak negara merupakan cara untuk menyelamatkan diri dari kemiskinan. Semakin tinggi tingkat pendidikan seseorang, maka pengetahuan dan keahlian juga akan meningkat sehingga akan mendorong peningkatan produktivitas kerjanya. Rendahnya produktivitas kaum miskin dapat disebabkan oleh rendahnya akses mereka untuk memperoleh pendidikan.

\section{8) Hubungan Inflasi dengan Kemiskinan}

Inflasi adalah kenaikan harga-harga barang secara umum. Jika harga-harga naik secara drastis dalam periode tertentu, maka tingkat kemiskinan juga akan naik. Tingkat kemiskinan naik bila tingkat upah masyarakat tetap sedangkan harga barang-barang naik. Masyarakat yang awalnya dapat memenuhi kebutuhan,dengan terjadinyainflasi mengakibatkan mereka tidak dapat memenuhi kebutuhan dasarnya (Phutong dalam Nurfitri Yanti, 2011: 21).

\section{9) Hubungan Pengangguran dengan Kemiskinan}

Menurut Sukirno (2004), efek buruk dari pengangguran adalah mengurangi pendapatan masyarakat yang pada akhirnya mengurangi tingkat kemakmuran yang telah dicapai seseorang. Semakin rendah kesejahteraan masyarakat akibat menganggur tentunya akan meningkatkan peluang mereka terjebak dalam kemiskinan karena tidak memiliki pendapatan. Hal serupa dikemukakan oleh Dian Octaviani (2001), yaitu jumlah pengangguran erat kaitannya dengan kemiskinan yang penduduknya memiliki ketergantungan yang sangat besar terhadap pendapatan atau upah yang diperoleh pada saat itu. Hilangnya lapangan pekerjaan menyebabkan berkurangnya sebagian besar penerimaan yang digunakan untuk membeli kebutuhan sehari-hari. Artinya, semakin tinggi pengangguran maka akan meningkatkan kemiskinan.

\section{METODE}

Jenis penelitian yang digunakan adalah penelitian deskriptif kuantitatif. Jenis penelitian ini dipilih karena rancangan dalam penelitian ini adalah menganalisis guna mengetahui besarnya pengaruh variabel bebasterhadap variabel terikat, baik secara langsung maupun tidak langsung. Variabel bebas yang digunakan dalam penelitian ini adalah pertumbuhan ekonomi (X1), Upah Minimum Kota (X2), tingkat pendidikan (X3), dan inflasi (X4). Sedangkan, variabel terikat yang digunakan adalah tingkat pengangguran (Y1) dan kemiskinan (Y2).Pengumpulan data dilakukan dengan metode studi kepustakaan. Data yang telah terkumpul akan diolah dengan menggunakan teknik analisis jalur (path analysis) dengan bantuan program SPSS versi 23.0. Data yang digunakan dalam penelitian ini adalah data kuantitatif yang terdiri dari data PDRB Atas Dasar Harga Konstan, Upah Minimum Kota (UMK), rata-rata lama sekolah, inflasi, jumlah pengangguran, dan jumlah penduduk miskin di Kota Samarinda pada tahun 2005-2014.

Alat analisis data yang digunakan adalah analisis jalur (path analysis). Metode analisis jalur digunakan untuk menganalisis pola hubungan antar variabel. Tujuan analisis jalur adalah untuk mengetahui pengaruh langsung maupun tidak langsung melalui seperangkat variabel bebas terhadap variabel terikat. Berdasarkan kerangka konsep, maka terdapat 2 (dua) bentuk persamaan yang dapat disusun, yaitu:

$$
\begin{aligned}
& \mathrm{Y} 1=\alpha 1 \mathrm{X} 1+\alpha 2 \mathrm{X} 2+\alpha 3 \mathrm{X} 3+\alpha 4 \mathrm{X} 4+\mathrm{e} 1 \\
& \mathrm{Y} 2=\beta 1 \mathrm{X} 1+\beta 2 \mathrm{X} 2+\beta 3 \mathrm{X} 3+\beta 4 \mathrm{X} 4+\beta 5 \mathrm{Y} 1+\mathrm{e} 2
\end{aligned}
$$




$$
\begin{array}{ll}
\text { dimana: } & \\
\mathrm{X} 1 & =\text { Pertumbuhan Ekonomi } \\
\mathrm{X} 2 & =\text { Upah Minimum Kota } \\
\mathrm{X} 3 & =\text { Tingkat Pendidikan } \\
\mathrm{X} 4 & =\text { Inflasi } \\
\mathrm{Y} 1 & =\text { Tingkat Pengangguran } \\
\mathrm{Y} 2 & =\text { Tingkat Kemiskinan } \\
\alpha \text { dan } \beta & =\text { Koefisien regresi } \\
\mathrm{e} & =\text { Error } \\
\text { Taraf signifikansi yang digunakan adalah } \mathrm{a}=10 \% \text { atau } 0,10 .
\end{array}
$$

\section{HASIL DAN PEMBAHASAN}

\section{Pengaruh Pertumbuhan Ekonomi (X1) terhadap Tingkat Pengangguran (Y1)}

Nilai t-hitung untuk variabel pertumbuhan ekonomi adalah 1,569, sementara itu nilai t-tabel untuk $\mathrm{n}=10$ dengan tingkat signifikansi 10\% adalah 1,372. Artinya, t-hitung $>\mathrm{t}$-tabel $(1,569>1,372)$, sehingga diinterpretasikan bahwa variabel pertumbuhan ekonomi berpengaruh terhadap tingkat pengangguran.Namun, nilai signifikansi menunjukkan $0,177>0,10$ yang artinya pengaruh variabel pertumbuhan ekonomi tidak signifikan terhadap tingkat pengangguran. Pengambilan keputusan didasarkan pada kriteria uji signifikansi, sehingga hipotesis $\mathrm{H} 1$ dalam penelitian ini yang berbunyi "pertumbuhan ekonomi berpengaruh langsung dan signifikan terhadap tingkat pengangguran" ditolak.

Pengaruh pertumbuhan ekonomi secara langsung terhadap tingkat penganggurantidak signifikan dengan nilai pengaruh langsung sebesar 0,269 . Hasil penelitian ini bertolak belakang dengan teori Hukum Okun yang dikemukakan oleh Arthur Okun yang menjelaskan bahwa tingkat pengangguran memiliki hubungan negatif dengan pertumbuhan GDP. Hal ini menjelaskan, jika GDP mengalami kenaikan, maka tingkat pengangguran akan turun. Jika GDP tidak mengalami pertumbuhan, maka tingkat pengangguran akan tetap pada tingkat yang sama, bahkan akan naik sebesar 1,5\% dari kondisi sebelumnya (Mankiw, 2006:248, terjemahan Haris Munandar, 2006). Berdasarkan teori tersebut, pertumbuhan ekonomi berkorelasi negatifdengan tingkat pengangguran. Namun, berdasarkan hasil analisis dalam penelitian ini, kenyataan yang terjadi di lapangan adalah pengaruh dari pertumbuhan ekonomi tersebut bersifat positif namun tidak signifikan terhadap tingkat pengangguran di Kota Samarinda.

Pengaruh yang positif namun tidak signifikan dari pertumbuhan ekonomi terhadap tingkat pengangguran ini lebih disebabkan oleh laju pertumbuhan ekonomi Kota Samarinda yang cenderung melambat selama kurun waktu tahun 2005 hingga 2014. Di sisi lain, tingkat pengangguran di Kota Samarinda cenderung mengalami penurunan yang disebabkan adanya pertumbuhan ekonomi di kota tersebut walaupun pertumbuhan ekonominya cenderung melambat. Hal inilah yang menyebabkan pengaruh pertumbuhan ekonomi terhadap tingkat pengangguran di Kota Samarinda menunjukkan hubungan yang positif namun tidak signifikan.

Langkah nyata yang dapat dilakukan oleh pemerintah dan pihak swasta untuk dapat meningkatkan peran pertumbuhan ekonomi dalam mengurangi tingkat pengangguran di Kota Samarinda adalah dengan mempercepat peningkatan laju pertumbuhan ekonomi setiap tahunnya serta menjaga konsistensi peningkatan pertumbuhan ekonomi. Hal ini bertujuan agar dapat mempercepat penurunan tingkat pengangguran di kota tersebut.

\section{Pengaruh Upah Minimum Kota (X2) terhadap Tingkat Pengangguran (Y1)}

Nilai t-hitung untuk variabel upah minimum kota adalah -2,953, sementara itu nilai t-tabel untuk $\mathrm{n}=10$ dengan tingkat signifikansi $10 \%$ adalah 1,372 . Artinya t-hitung $>\mathrm{t}$-tabel $(-2,953>1,372)$, sehingga diinterpretasikan bahwa variabel upah minimum kotaberpengaruh terhadap tingkat pengangguran.Hasil analisis ini diperkuat oleh nilai signifikansi $0,032<0,10$ yang artinya pengaruh variabel upah minimum kotasignifikan terhadap tingkat pengangguran. Dengan demikian, hipotesis H1 dalam penelitian ini yang berbunyi "upah minimum kota berpengaruh langsung dan signifikan terhadap tingkat pengangguran" diterima. 
Pengaruh upah minimum kota secara langsung terhadap tingkat pengangguran signifikan dengan nilai pengaruh langsung sebesar $-1,269$. Hasil penelitian ini bertolak belakang dengan pendapat yang dikemukakan oleh Todaro (2000) dan Sumarsono (2003) yang mengatakan bahwa semakin tinggi tingkat upah yang ditawarkan maka permintaan terhadap tenaga kerja baru maupun penggunaan tenaga kerja yang sudah ada semakin berkurang sehingga pengangguran akan meningkat. Pendapat yang sama juga dikemukakan oleh Ehrenberg dan Smith (1998: 68) dalam Abdul Haris (2013: 20) yang menyatakan apabila terdapat kenaikan tingkat upah rata-rata, maka akan diikuti oleh turunnya jumlah tenaga kerja yang diminta, berarti akan terjadi pengangguran.

Hal ini mengindikasikan bahwa, seharusnya, jika semakin tinggi upah minimum yang ditetapkan di suatu daerah, maka tingkat pengangguran akan semakin banyak di daerah tersebut yang disebabkan berkurangnya permintaan terhadap tenaga kerja. Namun, kenyataan yang terjadi di lapangan adalah walaupun upah minimum kota (UMK) Samarinda selalu mengalami peningkatan sejak tahun 2005 hingga 2014, namun jumlah serta tingkat penganggurancenderung mengalami penurunan, bahkan peningkatan UMK tersebut berpengaruh signifikan terhadap berkurangnya tingkat pengangguran di kota tersebut.

Pengaruh yang signifikan terhadap tingkat pengangguran ini disebabkan oleh kegiatan perekonomian di Kota Samarinda yang semakin membaik dan berkembang dari tahun ke tahun. Berkembangnya kegiatan perekonomian ini mengakibatkan semakin banyak tenaga kerja yang dibutuhkan. Hal tersebut pada akhirnya mengakibatkan jumlah pengangguran semakin berkurang walaupun UMK di Kota Samarinda selalu meningkat selama kurun waktu tersebut.

\section{Pengaruh Tingkat Pendidikan (X3) terhadap Tingkat Pengangguran (Y1)}

Nilai t-hitung untuk variabel tingkat pendidikan adalah 1,286, sementara itu nilai t-tabel untuk $\mathrm{n}$ $=10$ dengan tingkat signifikansi $10 \%$ adalah 1,372. Artinya t-hitung $<\mathrm{t}$-tabel $(1,286<1,372)$, sehingga diinterpretasikan bahwa variabel tingkat pendidikan tidak berpengaruh terhadap tingkat pengangguran.Hasil analisis ini diperkuat oleh nilai signifikansi 0,255>0,10 yang artinya pengaruh variabel tingkat pendidikan tidak signifikan terhadap tingkat pengangguran. Dengan demikian, hipotesis H1 dalam penelitian ini yang berbunyi "tingkat pendidikan berpengaruh langsung dan signifikan terhadap tingkat pengangguran" ditolak.

Pengaruh tingkat pendidikan secara langsung terhadap tingkat pengangguran tidak signifikan dengan nilai pengaruh langsung sebesar 0,554 . Hasil penelitian ini bertolak belakang dengan pendapat yang dikemukakan oleh Todaro dan Smith (2004) yang mengatakan bahwa pendidikan memainkan kunci dalam membentuk kemampuan untuk menyerap teknologi modern dan untuk mengembangkan kapasitas seseorang agar tercipta pertumbuhan serta pembangunan yang berkelanjutan. Dalam konteks ini, pendidikan dianggap sebagai alat untuk mencapai target yang berkelanjutan, karena dengan pendidikan yang lebih tinggi, jumlah tenaga kerja yang terserap akan meningkat sehingga jumlah pengangguran berkurang. Berdasarkan teori tersebut, tingkat pendidikanberkorelasi negatif dengan tingkat pengangguran. Namun, berdasarkan hasil analisis dalam penelitian ini, kenyataan yang terjadi di lapangan adalah pengaruh dari tingkat pendidikan tersebut bersifat positif namun tidak signifikan terhadap tingkat pengangguran di Kota Samarinda.

Pengaruh yang positif namun tidak signifikan dari tingkat pendidikan terhadap tingkat pengangguran ini lebih disebabkan oleh peningkatan jumlah lulusan dengan tingkat pendidikan yang tinggi di Kota Samarinda tidak diimbangi dengan peningkatan ketersediaan lapangan kerja. Hal tersebut menyebabkan semakin banyak lulusan dengan tingkat pendidikan tinggi yang siap memasuki dunia kerja tidak dapat memperoleh pekerjaan sehingga pada akhirnya menyebabkan semakin banyak jumlah pengangguran di Kota Samarinda walaupun tingkat pendidikan masyarakatnya juga selalu meningkat selama kurun waktu tahun 2005 hingga 2014.

Langkah nyata yang dapat dilakukan oleh pemerintah dan pihak swasta untuk dapat meningkatkan pengoptimalan para lulusan dengan tingkat pendidikan yang tinggi dalam mengurangi tingkat pengangguran di Kota Samarinda adalah dengan meningkatkan penyediaan jumlah lapangan kerja baru serta melakukan pemerataan jenis lapangan kerja baru yang disediakan. Hal ini bertujuan agar tingkat pendidikan yang tinggi yang telah dilalui oleh masyarakat tidak sia-sia sehingga mereka 
dapat segera memperoleh pekerjaan yang pada akhirnya hal tersebut dapat mengurangi tingkat pengangguran di Kota Samarinda.

\section{Pengaruh Inflasi (X4) terhadap Tingkat Pengangguran (Y1)}

Nilai t-hitung untuk variabel inflasi adalah 1,025, sementara itu nilai t-tabel untuk $\mathrm{n}=10$ dengan tingkat signifikansi $10 \%$ adalah 1,372. Artinya, t-hitung $<$ t-tabel $(1,025<1,372)$, sehingga diinterpretasikan bahwa variabel inflasi tidak berpengaruh terhadap tingkat pengangguran.Hasil analisis ini diperkuat oleh nilai signifikansi $0,352>0,10$ yang artinya pengaruh variabel inflasi tidak signifikan terhadap tingkat pengangguran. Dengan demikian, hipotesis H1 dalam penelitian ini yang berbunyi "inflasi berpengaruh langsung dan signifikan terhadap tingkat pengangguran" ditolak.

Pengaruh inflasi secara langsung terhadap tingkat pengangguran tidak signifikan dengan nilai pengaruh langsung sebesar 0,184 . Hasil penelitian ini, walaupun tidak signifikan, sesungguhnya sejalan dengan pendapat yang dikemukakan oleh Sukirno (2002) yang mengatakan bahwa tingkat inflasi memiliki hubungan positif terhadap pengangguran. Jika tingkat inflasi yang dihitung adalah inflasi yang terjadi pada harga-harga secara umum, maka tingginya tingkat inflasi yang terjadi akan berakibat pada peningkatan pada tingkat bunga (pinjaman). Oleh karena itu, dengan tingkat bunga yang tinggi akan mengurangi investasi untuk mengembangkan sektor-sektor yang produktif. Hal ini akan berpengaruh pada jumlah pengangguran yang tinggi karena rendahnya kesempatan kerja sebagai akibat dari rendahnya investasi.

Berdasarkan teori tersebut, inflasi berkorelasi positif dengan tingkat pengangguran. Namun, berdasarkan hasil analisis dalam penelitian ini, kenyataan yang terjadi di lapangan adalah pengaruh dari inflasi tersebut tidak signifikan terhadap tingkat pengangguran di Kota Samarinda. Pengaruh yang tidak signifikan dari inflasi terhadap tingkat pengangguran ini lebih disebabkan oleh masih sedikitnya penyediaan lapangan kerja baru di Kota Samarinda. Sehingga, walaupun tingkat inflasi di kota tersebut cenderung mengalami penurunan selama kurun waktu tahun 2005 hingga 2014, dimana tingkat pengangguran juga cenderung mengalami penurunan, namun rendahnya tingkat inflasi tersebut tidak memberikan dampak yang berarti dalam mengurangi tingkat pengangguran. Selain itu, tingkat inflasi yang berfluktuasi tidak terkendali selama kurun waktu tersebut juga menjadi penyebab masih banyaknya jumlah pengangguran di Kota Samarinda.

Solusi yang dapat dilakukan oleh pemerintah adalah lebih aktif campur tangan dalam kegiatan perekonomian terutama dalam mengendalikan tingkat inflasi di Kota Samarinda agar tingkat inflasi tersebut memiliki pergerakan yang lebih stabil. Selain itu, dengan bantuan pihak swasta, pemerintah harus segera meningkatkan penyediaan jumlah lapangan kerja baru agar dapat segera mengurangi tingkat pengangguran di Kota Samarinda.

\section{Pengaruh Pertumbuhan Ekonomi (X1) terhadap Tingkat Kemiskinan (Y2)}

Nilai t-hitung untuk variabel pertumbuhan ekonomi adalah $-2,502$, sementara itu nilai t-tabel untuk $\mathrm{n}=10$ dengan tingkat signifikansi $10 \%$ adalah 1,372. Artinya t-hitung $>\mathrm{t}$-tabel $(-2,502>1,372)$, sehingga diinterpretasikan bahwa variabel pertumbuhan ekonomi berpengaruh terhadap tingkat kemiskinan.Hasil analisis ini diperkuat oleh nilai signifikansi $0,067<0,10$ yang artinya pengaruh variabel pertumbuhan ekonomi signifikan terhadap tingkat kemiskinan. Dengan demikian, hipotesis H1 dalam penelitian ini yang berbunyi "pertumbuhan ekonomi berpengaruh langsung dan signifikan terhadap tingkat kemiskinan" diterima.

Pengaruh pertumbuhan ekonomi secara langsung terhadap tingkat kemiskinan signifikan dengan nilai pengaruh langsung sebesar -0,607. Hasil penelitian ini sejalan dengan pendapat yang dikemukakan oleh Sukirno (2006) yang mengatakan bahwa pertumbuhan ekonomi yang tinggi dan berkelanjutan menyebabkan peningkatan permintaan akan tenaga kerja dan peningkatan upah yang pada akhirnya mengurangi kemiskinan. Pertumbuhan ekonomi juga memperbaiki pendapatan publik dan meningkatkan pengeluaran pemerintah untuk prasarana fisik dan sosial, sehingga membantu mengurangi kemiskinan.

Berdasarkan teori tersebut, dapat dikatakan bahwa mempercepatpeningkatan pertumbuhan ekonomi di suatu daerah akan mempengaruhi tingkat kemiskinan di daerah tersebut. Pertumbuhan ekonomi Kota Samarinda relatif mengalami penurunan sejak tahun 2005 hingga 2014, dimana tingkat 
kemiskinancenderung meningkat setiap tahunnya selama kurun waktu yang sama. Hal ini mengindikasikan bahwa tingkat kemiskinan di Kota Samarinda turut dipengaruhi olehcepat-lambatnya pertumbuhan ekonomi di kota tersebut, dimana pertumbuhan ekonominya relatif mengalami penurunan sehingga jumlah penduduk miskin cenderung meningkat.

Pengaruh yang negatif dan signifikan terhadap tingkat kemiskinan tersebut dikarenakan dengan melambatnya laju pertumbuhan ekonomi yang terjadi maka menyebabkan berkurangnya permintaan akan tenaga kerja serta tidak adanya peningkatan upah yang diberikan kepada tenaga kerja. Hal tersebut pada akhirnya menyebabkan jumlah penduduk miskin bertambah sehingga tingkat kemiskinan akan meningkat.Selain itu, melambatnya laju pertumbuhan ekonomi di Kota Samarinda juga menyebabkan pemerintah tidak dapat meningkatkan pengeluaran untuk menyediakan prasarana fisik dan sosial yang dapat membantu mengurangi kemiskinan.Permasalahan kemiskinan tersebut dapat diatasi dengan cara mempercepat serta menjaga konsistensi peningkatan laju pertumbuhan ekonomi di Kota Samarinda agar dapat segera mengurangi tingkat kemiskinan di kota tersebut.

\section{Pengaruh Upah Minimum Kota (X2) terhadap Tingkat Kemiskinan (Y2)}

Nilai t-hitung untuk variabel upah minimum kota adalah 2,025, sementara itu nilai t-tabel untuk $\mathrm{n}=10$ dengan tingkat signifikansi $10 \%$ adalah 1,372. Artinya t-hitung $>\mathrm{t}$-tabel $(2,025>1,372)$, sehingga diinterpretasikan bahwa variabel upah minimum berpengaruh terhadap tingkat kemiskinan.Namun, nilai signifikansi menunjukkan 0,113>0,10 yang artinya pengaruh variabel upah minimum kota tidak signifikan terhadap tingkat kemiskinan. Pengambilan keputusan didasarkan pada kriteria uji signifikansi, sehingga hipotesis $\mathrm{H}_{1}$ dalam penelitian ini yang berbunyi "upah minimum kota berpengaruh langsung dan signifikan terhadap tingkat kemiskinan" ditolak.

Pengaruh upah minimum kota secara langsung terhadap tingkat kemiskinantidak signifikan dengan nilai pengaruh langsung sebesar 1,669. Hasil penelitian ini bertolak belakang dengan pendapat yang dikemukakan Budi Santoso (2012) yang mengatakan bahwa peningkatan upah minimum dipercaya meningkatkan standar kehidupan buruh, mengurangi kemiskinan, mendorong perusahaan lebih efisien, sekaligus menciptakan efek beruntun lewat peningkatan konsumsi ke peluang kerja baru. Peningkatan upah minimum juga akan mengurangi beban pemerintah untuk biaya jaminan sosial akibat turunnya kelompok miskin yang disubsidi. Berdasarkan teori tersebut, dapat dikatakan bahwa, seharusnya, peningkatan yang terjadi pada upah minimum di suatu daerah akan mengurangi tingkat kemiskinan di daerah tersebut. Namun, kenyataan yang terjadi di lapangan adalah walaupun upah minimum kota (UMK) Samarinda selalu meningkat sejak tahun 2005 hingga 2014, namuntingkat kemiskinan di kota tersebut cenderung meningkat selama kurun waktu yang sama.

Pengaruh yang positif namun tidak signifikan terhadap tingkat kemiskinan ini bisa disebabkan oleh berbagai macam faktor. Misalnya, semakin banyaknya jumlah penduduk yang tidak bekerja, baik yang memang merupakan penduduk Kota Samarinda maupun penduduk yang bermigrasi dari luar daerah dan menetap di Kota Samarinda. Hal ini mengakibatkan peningkatan yang terjadi pada UMK Samarinda tidak berdampak signifikan pada berkurangnya tingkat kemiskinan karena peningkatan UMK tersebut hanya berdampak pada penduduk yang memiliki pekerjaan. Selain itu, tingkat harga barang dan jasa yang selalu meningkat menjadikan standar kebutuhan hidup layak (KHL) juga terus meningkat.Hal ini mengakibatkan tingkat kemiskinan tidak dapat berkurang walaupun UMK Samarinda selalu meningkat setiap tahunnya.

Permasalahan ini dapat diatasi dengan langkah pemerintah segera menetapkan kebijakan pengentasan kemiskinan yang tepat, misalnya dengan menyediakan lebih banyak lapangan kerja baru, mengendalikan tingkat harga-harga kebutuhan dasar, serta membatasi jumlah penduduk yang bermigrasi ke Kota Samarinda tanpa pekerjaan yang jelas. Hal ini bertujuan agar dapat segera mengurangi tingkat kemiskinan di Kota Samarinda sehingga peningkatan UMK Samarinda dapat meningkatkan kesejahteraan penduduk di kota tersebut.

\section{Pengaruh Tingkat Pendidikan (X3) terhadap Tingkat Kemiskinan (Y2)}

Nilai t-hitung untuk variabel tingkat pendidikanadalah $-2,344$, sementara itu nilai t-tabel untuk $\mathrm{n}$ $=10$ dengan tingkat signifikansi $10 \%$ adalah 1,372. Artinya t-hitung $>\mathrm{t}$-tabel $(-2,344>1,372)$, sehingga diinterpretasikan bahwa variabel tingkat pendidikan berpengaruh terhadap tingkat 
kemiskinan.Hasil ini diperkuat oleh nilai signifikansi 0,079>0,10 yang artinya pengaruh variabel tingkat pendidikan signifikan terhadap tingkat kemiskinan. Dengan demikian, hipotesis H1 dalam penelitian ini yang berbunyi "tingkat pendidikan berpengaruh langsung dan signifikan terhadap tingkat kemiskinan" diterima.

Pengaruh tingkat pendidikan secara langsung terhadap tingkat kemiskinansignifikan dengan nilai pengaruh langsung sebesar -1,350. Hasil penelitian ini sejalan dengan pendapat yang dikemukakan oleh Simmons (dalam Todaro, 1994) yang mengatakan bahwa pendidikan di banyak negara merupakan cara untuk menyelamatkan diri dari kemiskinan. Semakin tinggi tingkat pendidikan seseorang, maka pengetahuan dan keahlian juga akan meningkat sehingga akan mendorong peningkatan produktivitas kerjanya. Berdasarkan teori tersebut, dapat dikatakan bahwa semakin tinggi tingkat pendidikan seseorang, maka orang tersebut akan memiliki kemampuan lebih untuk memenuhi kebutuhan dasarnya, sehingga dapat keluar dari lingkaran kemiskinan. Artinya, semakin tinggi tingkat pendidikan di suatu daerah, maka akan mengurangi tingkat kemiskinan di daerah tersebut.

Sesuai dengan teori di atas, pengaruh tingkat pendidikan yang negatif dan signifikan terhadap tingkat kemiskinan di Kota Samarinda dikarenakan tingkat pendidikan masyarakat di kota tersebut selalu meningkat sejak tahun 2005 hingga 2014. Tingkat pendidikan yang selalu meningkat tersebut mengakibatkan pengetahuan dan keahlian masyarakat juga meningkat sehingga dapat mendorong peningkatan produktivitas kerjanya. Hal tersebut menyebabkan mereka memiliki kemampuan lebih untuk memenuhi kebutuhan dasarnya, sehingga dapat keluar dari lingkaran kemiskinan yang pada akhirnya turut mengurangi tingkat kemiskinan di Kota Samarinda.

\section{Pengaruh Inflasi (X4) terhadap Tingkat Kemiskinan (Y2)}

Nilai t-hitung untuk variabel inflasi adalah $-0,582$, sementara itu nilai t-tabel untuk $\mathrm{n}=10$ dengan tingkat signifikansi $10 \%$ adalah 1,372. Artinya t-hitung < t-tabel $(-0,582<1,372)$, sehingga diinterpretasikan bahwa variabel inflasi tidak berpengaruh terhadap tingkat kemiskinan.Hasil analisis ini diperkuat oleh nilai signifikansi 0,592>0,10 yang artinya pengaruh variabel inflasi tidak signifikan terhadap tingkat kemiskinan. Dengan demikian,hipotesis $\mathrm{H}_{1}$ dalam penelitian ini yang berbunyi "inflasi berpengaruh langsung dan signifikan terhadap tingkat kemiskinan" ditolak.

Pengaruh inflasi secara langsung terhadap tingkat kemiskinantidak signifikan dengan nilai pengaruh langsung sebesar $-0,133$. Hasil penelitian ini bertolak belakang dengan pendapat yang dikemukakan oleh Phutong (dalam Nurfitri Yanti, 2011: 21) yang mengatakan jika harga-harga naik secara drastis dalam periode tertentu, maka tingkat kemiskinan juga akan naik. Tingkat kemiskinan naik bila tingkat upah masyarakat tetap sedangkan harga barang-barang naik. Masyarakat yang awalnya dapat memenuhi kebutuhan, dengan terjadinya inflasi mengakibatkan mereka tidak dapat memenuhi kebutuhan dasarnya.Berdasarkan teori tersebut, dapat dikatakan bahwa, seharusnya, peningkatan yang terjadi pada tingkat inflasi di suatu daerah akan meningkatkan tingkat kemiskinan di daerah tersebut dan sebaliknya. Namun, kenyataan yang terjadi di lapangan adalah walaupun tingkat inflasi di Kota Samarinda cenderung mengalami penurunan sejak tahun 2005 hingga 2014, namun tingkat kemiskinan di kota tersebut cenderung meningkat selama kurun waktu yang sama.

Pengaruh yang negatif namun tidak signifikan terhadap tingkat kemiskinan ini bisa disebabkan oleh semakin banyaknya jumlah penduduk yang tidak bekerja, baik yang memang merupakan penduduk Kota Samarinda maupun penduduk yang bermigrasi dari luar daerah dan menetap di Kota Samarinda. Hal ini mengakibatkan rendahnya tingkat inflasi yang terjadi di Kota Samarinda tidak berdampak signifikan pada berkurangnya tingkat kemiskinan karena masih banyaknya penduduk yang tidak memiliki penghasilan untuk memenuhi kebutuhan hidupnya.Permasalahan ini dapat diatasi dengan langkah pemerintah segera menetapkan kebijakan pengentasan kemiskinan yang tepat, misalnya dengan menyediakan lebih banyak lapangan kerja baru serta membatasi jumlah penduduk yang bermigrasi ke Kota Samarinda tanpa pekerjaan yang jelas. Hal ini bertujuan agar pengendalian tingkat inflasi yang telah dilakukan oleh pemerintah dapat berdampak nyata dalam mengurangi tingkat kemiskinan di Kota Samarinda. 


\section{Pengaruh Tingkat Pengangguran (Y1) terhadap Tingkat Kemiskinan (Y2)}

Nilai t-hitung untuk variabel tingkat pengangguran adalah 2,703, sementara itu nilai t-tabel untuk $\mathrm{n}=10$ dengan tingkat signifikansi $10 \%$ adalah 1,372. Artinya t-hitung $>\mathrm{t}$-tabel $(2,703>1,372)$, sehingga diinterpretasikan bahwa variabel tingkat pengangguran berpengaruh terhadap tingkat kemiskinan.Hasil analisis ini diperkuat oleh nilai signifikansi $0,054<0,10$ yang artinya pengaruh variabel tingkat pengangguran signifikan terhadap tingkat kemiskinan. Dengan demikian hipotesis $\mathrm{H}_{1}$ dalam penelitian ini yang berbunyi "tingkat pengangguran berpengaruh langsung dan signifikan terhadap tingkat kemiskinan" diterima.

Pengaruh tingkat pengangguran secara langsung terhadap tingkat kemiskinan signifikan dengan nilai pengaruh langsung sebesar 1,400. Hasil penelitian ini sejalan dengan pendapat yang dikemukakan oleh Dian Octaviani (2001) dan Sukirno (2004). Dian Octaviani mengatakan jumlah pengangguran erat kaitannya dengan kemiskinan yang penduduknya memiliki ketergantungan yang sangat besar terhadap pendapatan atau upah yang diperoleh pada saat itu. Hilangnya lapangan pekerjaan menyebabkan berkurangnya sebagian besar penerimaan yang digunakan untuk membeli kebutuhan sehari-hari. Artinya, semakin tinggi pengangguran maka akan meningkatkan kemiskinan. Hal serupa dikemukakan oleh Sukirno yang mengatakan efek buruk dari pengangguran adalah mengurangi pendapatan masyarakat yang pada akhirnya mengurangi tingkat kemakmuran yang telah dicapai seseorang. Semakin rendah kesejahteraan masyarakat akibat menganggur tentunya akan meningkatkan peluang mereka terjebak dalam kemiskinan karena tidak memiliki pendapatan.

Berdasarkan teori tersebut, dapat dikatakan bahwa semakin tinggi tingkat pengangguran di suatu daerah, maka semakin tinggi pula tingkat kemiskinan di daerah tersebut.Pengaruh tingkat pengangguran yang positif dan signifikan terhadap tingkat kemiskinan di Kota Samarinda sesuai dengan teori di atas, dimana tingkat kemiskinan di Kota Samarinda secara persentase cenderung mengalami penurunan dikarenakan tingkat pengangguran juga mengalami penurunan. Hal tersebut disebabkan kegiatan perekonomian di Kota Samarinda yang semakin membaik dan berkembang dari tahun ke tahun sehingga tingkat pengangguran semakin berkurang dan pada akhirnya tingkat kemiskinan juga berkurang.

\section{Pengaruh Pertumbuhan Ekonomi (X1) terhadap Tingkat Kemiskinan (Y2) melalui Tingkat Pengangguran (Y1)}

Nilai pengaruh tidak langsung pertumbuhan ekonomiterhadap tingkat kemiskinanmelalui tingkat pengangguran adalah sebesar 0,3766, sehingga diinterpretasikan bahwa pengaruh tidak langsung variabel pertumbuhan ekonomi melalui tingkat pengangguran terhadap tingkat kemiskinan tidak signifikan. Dengan demikian, hipotesis H1 dalam penelitian ini yang berbunyi "pertumbuhan ekonomi berpengaruh tidak langsung dan signifikan terhadap tingkat kemiskinan melalui tingkat pengangguran" ditolak.

Tingkat kemiskinan di Kota Samarinda yang cenderungmengalami peningkatan sejak tahun 2005 hingga 2014 ternyata berkorelasi positif dengan pertumbuhan ekonomiwalaupun pertumbuhan ekonomi tersebut cenderung mengalami penurunan sepanjang kurun waktu yang sama. Hal ini mengindikasikan bahwa tingkat kemiskinan di Kota Samarinda yang cenderung mengalami peningkatan tersebut lebih dipengaruhi oleh faktor lain di luar pertumbuhan ekonomi. Bahkan, berkurangnya tingkat pengangguran selama kurun waktu tersebut tidak memberikan pengaruh yang signifikan terhadap berkurangnya tingkat kemiskinan di Kota Samarinda.

Pengaruh yang positif namun tidak signifikan ini disebabkan laju pertumbuhan ekonomi di Kota Samarinda yang berfluktuasi tidak menentu, dimana hal ini menyebabkan pengurangan tingkat pengangguran menjadi tidak optimal. Pengurangan tingkat pengangguran yang tidak optimal tersebut pada akhirnya menyebabkan pengendalian tingkat kemiskinan juga tidak optimal, bahkan tingkat kemiskinan di Kota Samarinda cenderung mengalami peningkatan. Hal inilah yang menyebabkantingkat kemiskinantidak terpengaruh oleh laju pertumbuhan ekonomi yang terjadi di kota tersebut. 


\section{Pengaruh Upah Minimum Kota (X2) terhadap Tingkat Kemiskinan (Y2) melalui Tingkat Pengangguran (Y1)}

Nilai pengaruh tidak langsung upah minimum kota terhadap tingkat kemiskinan melalui tingkat pengangguran adalah sebesar -1,7766, sehingga diinterpretasikan bahwa pengaruh tidak langsung variabel upah minimum kota melalui tingkat pengangguran terhadap tingkat kemiskinan signifikan. Dengan demikian, hipotesis H1 dalam penelitian ini yang berbunyi "upah minimum kota berpengaruh tidak langsung dan signifikan terhadap tingkat kemiskinan melalui tingkat pengangguran" diterima.

Tingkat kemiskinan di Kota Samarinda yang cenderung mengalami peningkatan sejak tahun 2005 hingga 2014 ternyata berkorelasi negatif dengan upah minimum kota (UMK) walaupun UMK tersebut selalumengalami peningkatan sepanjang kurun waktu yang sama. Di sisi lain, UMK yang selalu mengalami peningkatan tersebut justru menyebabkan berkurangnya tingkat pengangguran di Kota Samarinda. Berkurangnya tingkat pengangguran inilah yang menyebabkan UMK berpengaruh negatif dan signifikan terhadap tingkat kemiskinan di kota tersebut. Dengan kata lain, peningkatan yang terjadi pada UMK berdampak nyata dalam mengurangi tingkat kemiskinan melalui tingkat pengangguran di Kota Samarinda.

\section{Pengaruh Tingkat Pendidikan (X3) terhadap Tingkat Kemiskinan (Y2) melalui Tingkat Pengangguran (Y1)}

Nilai pengaruh tidak langsung tingkat pendidikan terhadap tingkat kemiskinan melalui tingkat pengangguran adalah sebesar 0,7756 , sehingga diinterpretasikan bahwa pengaruh tidak langsung variabel tingkat pendidikan melalui tingkat pengangguran terhadap tingkat kemiskinan tidak signifikan. Dengan demikian, hipotesis H1 dalam penelitian ini yang berbunyi "tingkat pendidikan berpengaruh tidak langsung dan signifikan terhadap tingkat kemiskinan melalui tingkat pengangguran" ditolak.

Tingkat kemiskinan di Kota Samarinda yang cenderung mengalami peningkatan sejak tahun 2005 hingga 2014 ternyata berkorelasi positif dengan tingkat pendidikan, dimana tingkat pendidikan tersebut juga selalu mengalami peningkatan sepanjang kurun waktu yang sama walaupun seharusnya tingkat kemiskinan berkorelasi negatif dengan tingkat pendidikan. Hal ini mengindikasikan bahwa tingkat kemiskinan di Kota Samarinda yang cenderung meningkat tersebut lebih dipengaruhi oleh faktor lain di luar tingkat pendidikan. Bahkan, berkurangnya tingkat pengangguran selama kurun waktu tersebut tidak memberikan pengaruh yang signifikan terhadap berkurangnya tingkat kemiskinan di Kota Samarinda.

Pengaruh yang positif namun tidak signifikan ini disebabkan tingkat pendidikan masyarakat di Kota Samarinda yang selalu meningkat tersebut tidak optimal dalam mengurangi tingkat pengangguran, dimana masih banyak lulusan dengan pendidikan yang tinggi dan siap bekerja namun tidak dapat segera memperoleh pekerjaan yang disebabkan sedikitnya lapangan pekerjaan yang sesuai dengan latar belakang pendidikannya. Hal ini pada akhirnya menyebabkan tingkat kemiskinan juga tidak dapat dikendalikan dengan optimal karena masih banyak pengangguran walaupun mereka telah mengenyam pendidikan yang lebih tinggi.

\section{Pengaruh Inflasi (X4) terhadap Tingkat Kemiskinan (Y2) melalui Tingkat Pengangguran (Y1)}

Nilai pengaruh tidak langsung inflasi terhadap tingkat kemiskinan melalui tingkat pengangguran adalah sebesar 0,2576 , sehingga diinterpretasikan bahwa pengaruh tidak langsung variabel inflasi melalui tingkat pengangguran terhadap tingkat kemiskinan tidak signifikan. Dengan demikian, hipotesis $\mathrm{H} 1$ dalam penelitian ini yang berbunyi "inflasi berpengaruh tidak langsung dan signifikan terhadap tingkat kemiskinan melalui tingkat pengangguran" ditolak.

Tingkat kemiskinan di Kota Samarinda yang cenderung mengalami peningkatan sejak tahun 2005 hingga 2014 ternyata berkorelasi positif dengan tingkat inflasi yang terjadi walaupun tingkat inflasi tersebut cenderung mengalami penurunan sepanjang kurun waktu yang sama. Hal ini mengindikasikan bahwa tingkat kemiskinan di Kota Samarinda yang cenderung mengalami peningkatan tersebut lebih dipengaruhi oleh faktor lain di luar tingkat inflasi. Bahkan, berkurangnya 
tingkat pengangguran selama kurun waktu tersebut tidak memberikan pengaruh yang signifikan terhadap berkurangnya tingkat kemiskinan di Kota Samarinda.

Pengaruh yang positif namun tidak signifikan ini disebabkan oleh tingkat inflasi di Kota Samarinda yang berfluktuasi tidak menentu, dimana hal ini menyebabkan pengurangan tingkat pengangguran menjadi tidak optimal. Tingkat inflasi yang sering berfluktuasi tajam tersebut mengakibatkan sedikitnya penyediaan lapangan kerja baru di Kota Samarinda. Hal inilah yang menyebabkan tidak optimalnya pengurangan tingkat pengangguran di kota tersebut. Pengurangan tingkat pengangguran yang tidak optimal tersebut pada akhirnya menyebabkan pengendalian tingkat kemiskinan juga tidak optimal, sehingga tingkat inflasi yang rendah tidak terlalu berpengaruh pada pengurangan tingkat kemiskinan di Kota Samarinda.

\section{SIMPULAN} berikut:

Berdasarkan analisis dan pembahasan di atas, maka dapat diambil beberapa kesimpulan sebagai

1. Pengaruh pertumbuhanekonomi terhadap tingkat penganggurandi Kota Samarindamasih rendah karena pertumbuhan ekonomi yang cenderung melambatsehingga tidak terlalu berpengaruh terhadap berkurangnya tingkat pengangguran di Kota Samarinda.

2. Upah minimum kota(UMK) berpengaruh signifikanterhadap tingkat penganggurandi Kota Samarinda karena kegiatan perekonomian di Kota Samarinda yang semakin membaik dan berkembang dari tahun ke tahun yang mengakibatkan semakin banyak tenaga kerja yang dibutuhkan sehingga tingkat pengangguran berkurang.

3. Tingkat pendidikankurang berpengaruh terhadap tingkat penganggurandi Kota Samarinda karena peningkatan jumlah lulusan dengan tingkat pendidikan yang tinggi tidak diimbangi dengan peningkatan ketersediaan lapangan kerja sehingga semakin banyak lulusan dengan tingkat pendidikan tinggi yang siap memasuki dunia kerja tidak dapat memperoleh pekerjaan dan pada akhirnya menganggur.

4. Inflasiberpengaruh minimterhadap tingkat penganggurandi Kota Samarinda karena tingkat inflasi yang berfluktuasi tidak terkendali sehingga tingkat inflasi yang rendah sekalipun tidak memberikan dampak yang berarti dalam mengurangi tingkat pengangguran di Kota Samarinda.

5. Pertumbuhan ekonomiberpengaruh signifikan terhadap tingkat kemiskinan diKota Samarinda karena melambatnya laju pertumbuhan ekonomi yang terjadi menyebabkan berkurangnya permintaan akan tenaga kerja serta tidak adanya peningkatan upah yang diberikan kepada tenaga kerja sehingga menyebabkan tingkat kemiskinan meningkat.

6. Upah minimum kota(UMK) kurang berpengaruh terhadap tingkat kemiskinan di Kota Samarinda karena tingkat harga barang dan jasa yang selalu meningkat menjadikan standar kebutuhan hidup layak (KHL) juga terus meningkat sehingga tingkat kemiskinan tidak dapat berkurang walaupun UMK Samarinda selalu meningkat setiap tahunnya.

7. Tingkat pendidikanberpengaruh signifikan terhadap tingkat kemiskinandi Kota Samarinda karena pengetahuan dan keahlian masyarakat meningkat yang mendorong peningkatan produktivitas kerjanya dan menyebabkan mereka memiliki kemampuan lebih untuk memenuhi kebutuhan dasarnya sehingga dapat keluar dari lingkaran kemiskinan yang pada akhirnya turut mengurangi tingkat kemiskinan di Kota Samarinda.

8. Pengaruh inflasiterhadap tingkat kemiskinan di Kota Samarinda masih rendah karena semakin banyak jumlah penduduk yang tidak bekerja, baik yang memang merupakan penduduk Kota Samarinda maupun penduduk yang bermigrasi dari luar daerah dan menetap di Kota Samarinda sehingga mengakibatkan rendahnya tingkat inflasi yang terjadi di Kota Samarinda tidak berdampak signifikan pada berkurangnya tingkat kemiskinan.

9. Tingkat pengangguranberpengaruh signifikan terhadap tingkat kemiskinan di Kota Samarinda karenakegiatan perekonomian di Kota Samarinda yang semakin membaik dan berkembang dari tahun ke tahun sehingga tingkat pengangguran semakin berkurang dan pada akhirnya tingkat kemiskinan juga berkurang.

10. Pengaruh pertumbuhan ekonomi terhadaptingkat kemiskinanmelalui tingkat penganggurandi Kota Samarindamasih minim karena laju pertumbuhan ekonomi yang berfluktuasi tidak menentu, 
dimana hal ini menyebabkan pengurangan tingkat pengangguran menjadi tidak optimal yang pada akhirnya menyebabkan pengendalian tingkat kemiskinan juga tidak optimal, bahkan tingkat kemiskinan di Kota Samarinda cenderung mengalami peningkatan.

11. Upah minimum kota(UMK) berpengaruh signifikan terhadap tingkat kemiskinan melalui tingkat penganggurandi Kota Samarinda karena UMK yang selalu mengalami peningkatan tersebut justru menyebabkan berkurangnya tingkat pengangguran yang pada akhirnya menyebabkan berkurangnya tingkat kemiskinan.

12. Tingkat pendidikankurang berpengaruh terhadap tingkat kemiskinan melalui tingkat penganggurandi Kota Samarindakarena tingkat pendidikan masyarakat yang selalu meningkat tersebut tidak optimal dalam mengurangi tingkat pengangguran, dimana masih banyak lulusan dengan pendidikan yang tinggi dan siap bekerja namun tidak dapat segera memperoleh pekerjaan yang disebabkan sedikitnya lapangan pekerjaan yang sesuai dengan latar belakang pendidikannya sehingga menyebabkan tingkat kemiskinan juga tidak dapat dikendalikan dengan optimal.

13. Inflasiberpengaruh rendahterhadap tingkat kemiskinan melalui tingkat penganggurandi Kota Samarinda karena tingkat inflasi yang sering berfluktuasi tajam mengakibatkan sedikitnya penyediaan lapangan kerja baru yang menyebabkan tidak optimalnya pengurangan tingkat pengangguran sehingga tingkat inflasi yang rendah tidak terlalu berpengaruh pada pengurangan tingkat kemiskinan di Kota Samarinda.

\section{DAFTAR PUSTAKA}

Albertus Aditya, "Pengangguran.” https://id.m.wikipedia.org/wiki/pengangguran, diakses Juni 2016.

Andi Muh. Ichsan, 2012. Analisis Faktor-faktor yang Mempengaruhi Tingkat Kemiskinan di Kabupaten Takalar 1999-2010. Universitas Hasanuddin, Makassar.

Badan Perencanaan Pembangunan Daerah Kota Samarinda, Indikator Pembangunan Daerah Kota Samarinda.

Badan Pusat Statistik, "Kemiskinan." https://www.bps.go.id/Subjek/view/id/ 23\#subjekViewTab1, diakses November 2016.

Badan Pusat Statistik, Kota Samarinda Dalam Angka 2006-2015, Samarinda.

Boediono, 1999. Teori Pertumbuhan Ekonomi. Yogyakarta: BPFE UGM.

Budi Santoso, "Efek Kenaikan Upah Minimum.” http://budisansblog. blogspot.co.id/2012/12/efekkenaikan-upah-minimum, diakses Juli 2016.

Chriswardani Suryawati. "Memahami Kemiskinan secara Multidimensional." Jurnal Manajemen Pelayanan Kesehatan, Volume 8, Nomor 3, September 2005, hal.121-129.

Claudia Christi, 2013. "Faktor-faktor yang Mempengaruhi Pertumbuhan Ekonomi dan Investasi dalam Perekonomian Suatu Negara." http://claudiachristi.blogspot.co.id, diakses Desember 2015.

Desy Nathalya S., 2012. Analisis Faktor-faktor yang Mempengaruhi Pengangguran di Sumatera Utara. Fakultas Ekonomi, Universitas Sumatera Utara, Medan.

Dian Octaviani. "Inflasi, Pengangguran, dan Kemiskinan di Indonesia: Analisis Indeks Forrester Greer \& Horbecke." Media Ekonomi, Volume 7, Nomor 8, 2001, hal.100-118.

Dinas Tenaga Kerja dan Transmigrasi Kota Samarinda, Perkembangan Upah Minimum Kota Samarinda.

Ehrenberg, Ronald G. dan Smith, Robert S., 1998. "Modern Labor Economics: Theory and Public Policy," dalam Abdul Haris R., Analisis Penyerapan Tenaga Kerja Industri Tenun Sutera di Kabupaten Wajo. Fakultas Ekonomi dan Bisnis, Universitas Hasanuddin, Makassar. 2013, hal. 20-21. 
Endah Tri W., Mia Hardina, Shofyan Adi P., dan Yudi Guntara, 2010. "Arti Pendidikan dan Batasbatas Pendidikan." http://blog.umy.ac.id, diakses Maret 2016.

Faldi Alif, 2014. Analisis Pengaruh Pertumbuhan Ekonomi, Inflasi, dan Upah Minimum Regional terhadap Pengangguran di DKI Jakarta Tahun 1997-2012. Fakultas Ekonomi dan Bisnis, Universitas Gadjah Mada, Yogyakarta.

Ghozali, Imam, 2005. Aplikasi Analisis Multivariate dengan Program SPSS. Edisi Ketiga, Semarang: Badan Penerbit Universitas Diponegoro.

Ghozali, Imam, 2009. Ekonometrika: Teori, Konsep dan Aplikasi dengan SPSS 17. Semarang: Badan Penerbit Universitas Diponegoro.

Gujarati, Damodar N., 2003. Basic Econometrics. $4^{\text {th }}$ Edition, New York: McGraw Hill.

Haryani, Sri, 2002. Hubungan Industrial di Indonesia. Yogyakarta: UPP AMP YKPN.

I Wayan Sudiana dan I Ketut Sudiana. "Pengaruh PDRB, Pendidikan, dan Struktur Tenaga Kerja terhadap Kemiskinan di Provinsi Bali." E-Jurnal Ekonomi Pembangunan Universitas Udayana, Volume 4, Nomor 6, Juni 2015, hal.608-620. ISSN 2303-0178.

Jhingan, M.L., 2004. Ekonomi Pembangunan dan Perencanaan.Edisi Pertama, Jilid 10, Terjemahan D. Guritno,Jakarta: RajaGrafindo Persada.

Kadek Ivan Wiradinata dan Nengah Kartika. "Analisis Pengaruh Upah Minimum, Tingkat Pendidikan, dan Tingkat Pengangguran terhadap Tingkat Kemiskinan di Provinsi Bali Periode Tahun 19952012." E-Jurnal Ekonomi Pembangunan Universitas Udayana, Volume 4, Nomor 6, Juni 2015, hal.729-745. ISSN 2303-0178.

Keputusan Menteri Tenaga Kerja Nomor 13 Tahun 2012 tentang Perubahan Penghitungan KHL.

Mankiw, N. Gregory, 2006. Makroekonomi. Edisi Keenam, Terjemahan Haris Munandar. Jakarta: Erlangga.

Masyithoh Alkautsar, 2014. Analisis Dampak Kebijakan Upah Minimum terhadap Tingkat Kemiskinan Indonesia. Tesis. Fakultas Ekonomi dan Manajemen, Institut Pertanian Bogor.

Muliawati, Weni, 2007. “Jenis-jenis Pengangguran," dalam Zakapedia, Pengangguran: Pengertian, Jenis, dan Penyebab Pengangguran. www.artikelsiana.com/2015 / 08 / pengangguran pengertian - jenis-penyebab.html., 2015, diakses Agustus 2016.

Mulyani, 2010. "Faktor yang Mempengaruhi Pertumbuhan Ekonomi di Indonesia." http://rakilmu.blogspot.co.id, diakses Desember 2015.

Ni Ketut Eni Endrayani dan Made Heny Urmila Dewi. “Analisis Faktor-faktor yang Mempengaruhi Tingkat Kemiskinan Kabupaten/Kota di Provinsi Bali." E-Jurnal Ekonomi dan Bisnis Universitas Udayana, Volume 5, Nomor 1, 2016, hal.63-88. ISSN 2337-3067.

Nopirin, 1992. "Jenis-jenis Inflasi," dalam Vio Achfuda, Analisis Pengaruh Suku Bunga Kredit, PDB, Inflasi, dan Tingkat Teknologi terhadap PMDN di Indonesia Periode 1986-2008. Universitas Diponegoro, Semarang. 2010, hal. 41.

Nurfitri Yanti, 2011. Pengaruh Pertumbuhan Ekonomi, Inflasi, dan Tingkat Kesempatan Kerja terhadap Tingkat Kemiskinan di Indonesia Tahun 1999-2009. Universitas Pembangunan Nasional, Yogyakarta.

Okta Ryan Pranata Yudha, 2013. Pengaruh Pertumbuhan Ekonomi, Upah Minimum, Tingkat Pengangguran Terbuka, dan Inflasi terhadap Kemiskinan di Indonesia Tahun 2009-2011. Fakultas Ekonomi, Universitas Negeri Semarang.

Peraturan Menteri Tenaga Kerja dan Transmigrasi Nomor 7 Tahun 2013 tentang Upah Minimun.

Peraturan Pemerintah Nomor 78 Tahun 2015 tentang Pengupahan. 
Pratisto, Arif, 2009. Statistik Menjadi Mudah dengan SPSS 17. Jakarta: Elex Media Computindo.

Priyo Adi Nugroho, 2015.Pengaruh PDRB, Tingkat Pendidikan, dan Pengangguran terhadap Kemiskinan di Kota Yogyakarta Tahun 1999-2013. Fakultas Ekonomi, Universitas Negeri Yogyakarta.

Riduwan dan Engkos Achmad, 2013. Cara Menggunakan dan Memaknai Path Analysis (Analisis Jalur). Edisi Kelima, Bandung: Alfabeta.

Sarah Fauzia, "Dampak Kebijakan Upah Minimum terhadap Tingkat Pengangguran." https://www.academia.edu/13708465/Pengaruh_UMP_terhadap_tingkat_pengangguran, diakses Juli 2016.

Sharp, Ansel M., Register, Charles A., dan Cerimes, Paul W., 1996. "Economic of Social Issue," dalam Estomihi Hutabarat, Pengaruh Desentralisasi Fiskal, Pengeluaran Pemerintah, dan Pertumbuhan Ekonomi terhadap Kemiskinan: Studi Kasus Kabupaten/Kota Provinsi Kalimantan Timur Tahun 2002-2013. Fakultas Ekonomi, Universitas Atma Jaya, Yogyakarta. 2015, hal. 4.

Siti Amalia. "Pengaruh Pertumbuhan Ekonomi dan Inflasi terhadap Pengangguran Terbuka dan Kemiskinan di Kota Samarinda." Jurnal Ekonomika-Bisnis, Volume 5, Nomor 2, Juli 2014, hal.173-182.

Sukirno, Sadono, 2002. Makroekonomi Teori Pengantar. Edisi Ketiga, Jakarta: Raja Grafindo Persada.

Sukirno, Sadono, 2004.Makroekonomi Teori Pengantar. Edisi Ketiga, Jakarta: Raja Grafindo Persada.

Sukirno, Sadono, 2006.Makroekonomi Teori Pengantar. Edisi Ketiga, Jakarta: Raja Grafindo Persada.

Sukirno, Sadono, 2008.Mikroekonomi Teori Pengantar. Edisi Ketiga, Jakarta: Raja Grafindo Persada.

Sumarsono, Sony, 2003. Ekonomi Manajemen Sumber Daya Manusia dan Ketenagakerjaan. Yogyakarta: Graha Ilmu.

Surat Edaran Menteri Tenaga Kerja No. SE-07/MEN/1990 Tahun 1990 tentang Pengelompokan Komponen Upah dan Pendapatan Non Upah.

Sutarman Tarjo, 2011. "Pengertian Pendidikan." http://tarman-revolusimahasiswa.blogspot.com, diakses Maret 2016.

Tegar Rizki Akbar, 2013. Pengaruh Jumlah Penduduk, Tingkat Pengangguran, dan Tingkat Pendidikan terhadap Kemiskinan (Studi Kasus di Provinsi Jawa Timur). Fakultas Ekonomi dan Bisnis, Universitas Pembangunan Nasional "Veteran", Jawa Timur.

Todaro, Michael P., 1994. Pembangunan Ekonomi di Dunia Ketiga. Edisi Kedua, Terjemahan Haris Munandar, Jakarta: Erlangga.

Todaro, Michael P, 2000. Pembangunan Ekonomi di Dunia Ketiga. Edisi Ketujuh, Terjemahan Haris Munandar, Jakarta: Erlangga.

Todaro, Michael P, 2002. Pembangunan Ekonomi di Dunia Ketiga. Edisi Kedua,Terjemahan Haris Munandar, Jakarta: Erlangga.

Todaro, Michael P. dan Smith, Stephen C., 2004. Pembangunan Ekonomi di Dunia Ketiga. Edisi Kedelapan, Jilid 1, Terjemahan Haris Munandar, Jakarta: Erlangga.

Undang-undang Nomor 13 Tahun 2003 tentang Ketenagakerjaan.

Undang-undang Nomor 20 Tahun 2003 tentang Sistem Pendidikan Nasional.

Wage Indicator Foundation, "Komponen Standar Kebutuhan Hidup Layak (KHL)." http://www.gajimu.com/main/gaji/gaji-minimum/komponen-khl, diakses Juli 2016. 
Wage Indicator Foundation, "Pengertian Upah Minimum." http://www.gajimu.com/main/gaji /gajiminimum/pengertian-upah-minimum-2, diakses Juli 2016.

World Bank, 2005. Era Baru dalam Pengentasan Kemiskinan di Indonesia (Ikhtisar). Jakarta: The World Bank Office Jakarta.

Yarlina Yacoub. "Pengaruh Tingkat Pengangguran terhadapTingkat Kemiskinan Kabupaten/Kota di Provinsi Kalimantan Barat." Jurnal Ekonomi Sosial, Volume 8, Nomor 3, Oktober 2012, hal.176-185. ISSN 1693-9093.

Yeny Dharmayanti, 2011. Analisis Pengaruh PDRB, Upah, dan Inflasi terhadap Pengangguran Terbuka di Provinsi Jawa Tengah Tahun 1991-2009.Fakultas Ekonomi, Universitas Diponegoro, Semarang. 